\title{
Analysis of impact of EGR valve construction on the exhaust gas flow parameters in the engine
}

In this paper an analysis of the EGR valve design impact, in particular the outlet diameter, on the gas flow parameters in diesel engine (Z 1505) exhaust gas recirculation system of Zetor tractor was made. For this purpose the experimental and simulation studies of gas flow through the valve were carried out. The simulations using Fluent were made. Also distribution of the pressure and velocity vectors in the area of the valve outflow was presented. Analysis of the phenomena occurring in the exhaust area of the EGR valve was made. Also influence of the outlet diameter on the flow characteristics of the EGR valve was determined.

Keywords: EGR valve, exhaust gas recirculation, exhaust gas flow modeling

\section{Analiza wpływu konstrukcji zaworu EGR na parametry przepływu spalin w silniku}

W artykule dokonano analizy wptywu konstrukcji zaworu EGR, a w szczególności średnicy otworu wylotowego na parametry przeplywu spalin w układzie recyrkulacji spalin silnika o zapłonie samoczynnym typu $Z 1505$ ciagnika rolniczego marki Zetor. W tym celu przeprowadzono badania eksperymentalne i symulacyjne przepływu gazów przez zawór. Badania symulacyjne zrealizowano użyciu programu Fluent oraz przedstawiono rozkład wektorów prędkości i ciśnienia w obszarze wyplywu gazu z zaworu. Przeanalizowano zjawiska turbulencji zachodzace w obszarze wylotowym zaworu. Określono również wpływ średnicy wylotowej na charakterystykę przepływowa zaworu EGR.

Słowa kluczowe: zawór EGR, recyrkulacja spalin, modelowanie przepływu spalin

\section{Modeling of gas flow through the EGR valve}

In this article analysis of the flow of gases through the exhaust gas recirculation valve (EGR) was made. The valve was the component of the exhaust gas recirculation diesel engine Z1505, its structure is shown schematically in Fig. 1.

Role of the exhaust gas recirculation valve is to control flow quantity of gas supplied to the engine intake manifold. Because the costs involved in testing of valves in a laboratory environment are high and measurements are time-consuming therefore, to simulate a physical phenomena and processes in the valve numerical computational techniques are often used. The use of advanced computational programs allows the modeling and analysis of gas flows including the distribution of the velocity and pressure vectors.

One of such programs is FLUENT. Calculations performed with FLUENT package are based on the finite volume method [1, 2].

Simulation studies examined the usefulness of design a new type of EGR valve (Fig. 1) to control the amount of recirculated exhaust gas.

For simulation research a faithful representation of the actual geometry of element is very important [4]. For this purpose GAMBIT program was used

\section{Modelowanie przepływu gazu przez zawór EGR}

W artykule dokonano analizy przepływu gazów przez zawór recyrkulacji spalin (EGR) o konstrukcji przedstawionej schematycznie na rys. 1 , wchodzącego w skład układu recyrkulacji spalin silnika o zapłonie samoczynnym typu Z 1505.

Zadaniem zaworu recyrkulacji spalin jest kontrolowanie przepływu ilości spalin dostarczanych do kolektora doloto-

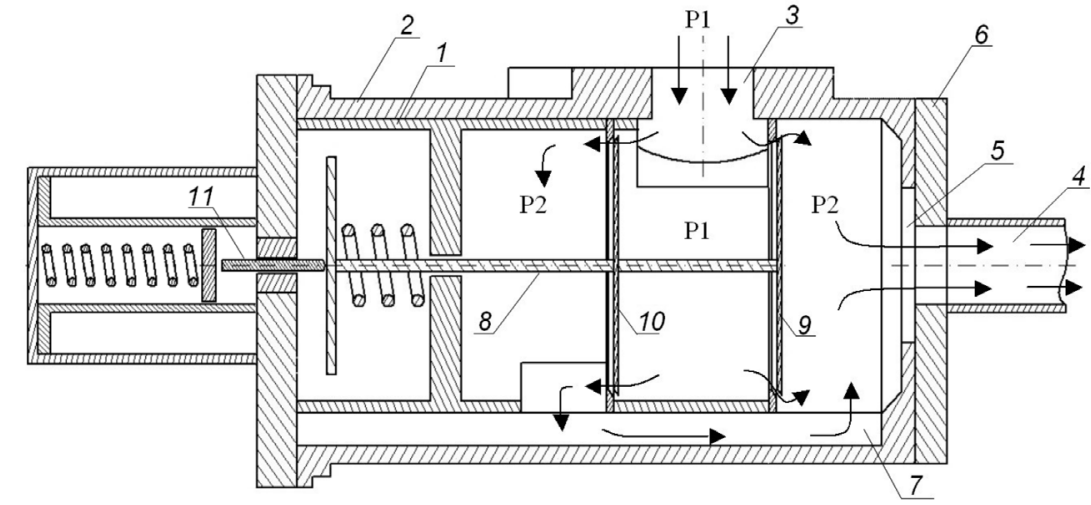

Fig. 1. Sketch of the most important construction elements of the EGR valve. 1 - valve housing, 2 - valve body, 3 - gas inlet, 4 - gas outlet 5 - outlet end of the housing, 6 - flange with an outlet hole and exhaust pipe, 7 - bypass channel, 8 - valve stem 9 - valve head, 10 - valve head, 11 - pusher

Rys. 1. Szkic najważniejszych elementów konstrukcyjnych zaworu EGR: 1 - korpus zaworu, 2 - obudowa zaworu, 3 -wlot gazu, 4-wylot gazu, 5-wylotowy otwór w korpusie, 6-kotnierz $z$ otworem i rura wylotowa, 7 - kanat bypass, 8 - trzon zaworu, 9 - grzybek zaworu, 10 - grzybek zaworu, 11 - popychacz 


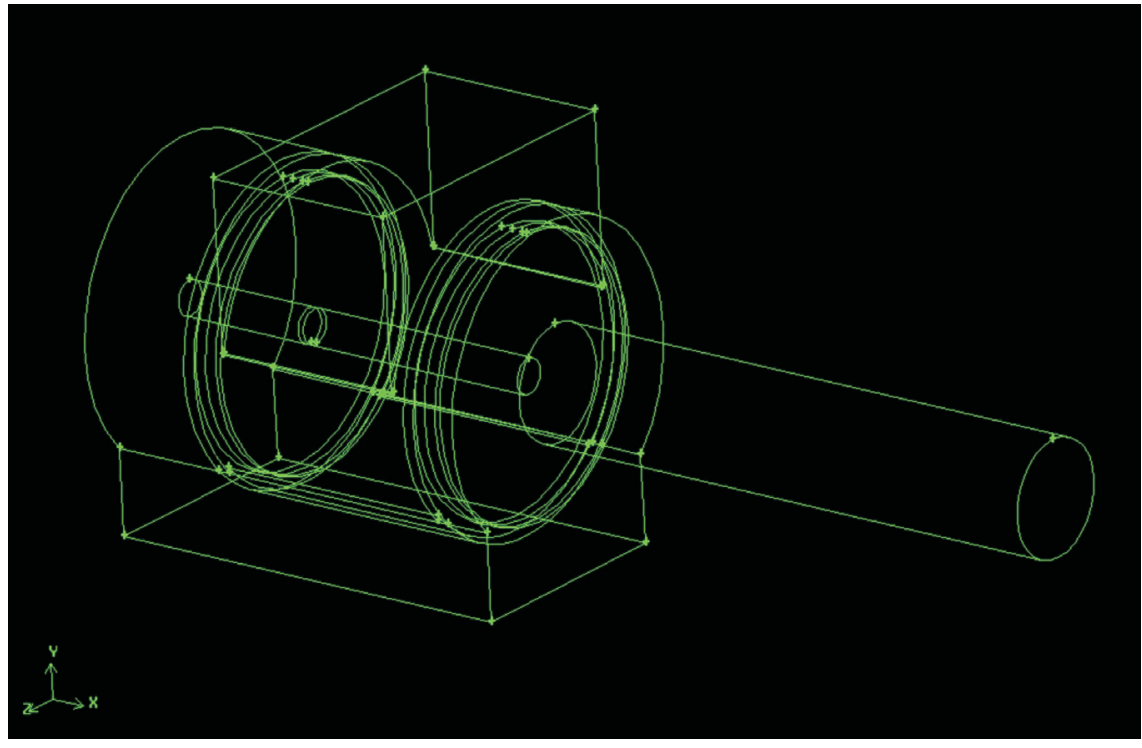

Fig. 2. EGR valve geometry mapped in the Gambit Rys. 2. Geometria zaworu EGR odwzorowana w programie Gambit wego silnika. Ponieważ nakłady finansowe związane badaniem takich zaworów w warunkach laboratoryjnych są wysokie a pomiary czasochłonne, to do symulowania przebiegu zjawisk i procesów fizycznych przez zawór często wykorzystuje się numeryczne techniki obliczeniowe. Dzięki zastosowaniu zaawansowanych programów obliczeniowych można modelować i analizować m.in. przepływy gazów w tym rozkład jego wektorów prędkości i ciśnienia. Jednym z takich programów jest FLUENT. Obliczenia wykonywane za pomocą pakietu FLUENT bazują na metodzie skończonych objętości $[1,2]$. W badaniach symulacyjne sprawdzono przydatność konstrukcji nowego typu zaworu EGR (rys. 1) do kontroli ilości recyrkulowanych spalin.

Podstawową w tego typu badaniach symulacyjnych jest wierne od-

(Fig. 2) and then digitizing the calculation area with use of tetrahedral mesh (Tetrahedral/Hybrid) was made (Fig. 3). The generated mesh was intentionally additionally concentrated in valve heads area, because at this place the largest changes in speed, gas pressure and flow turbulence caused by stenosis were expected.

Increased number of grid nodes was aimed at increasing the accuracy of the calculation and more precise representation of phenomena occurring in these areas of the valve.

The input data for the simulation was determined from the results of experimental studies.

Gas flow through the EGR valve for different positions of valve heads and constant differential pressure $\Delta \mathrm{P}=10$ $\mathrm{kPa}$ was simulated. Experimental studies [3] proved that the effective range of flow control by the EGR valve is

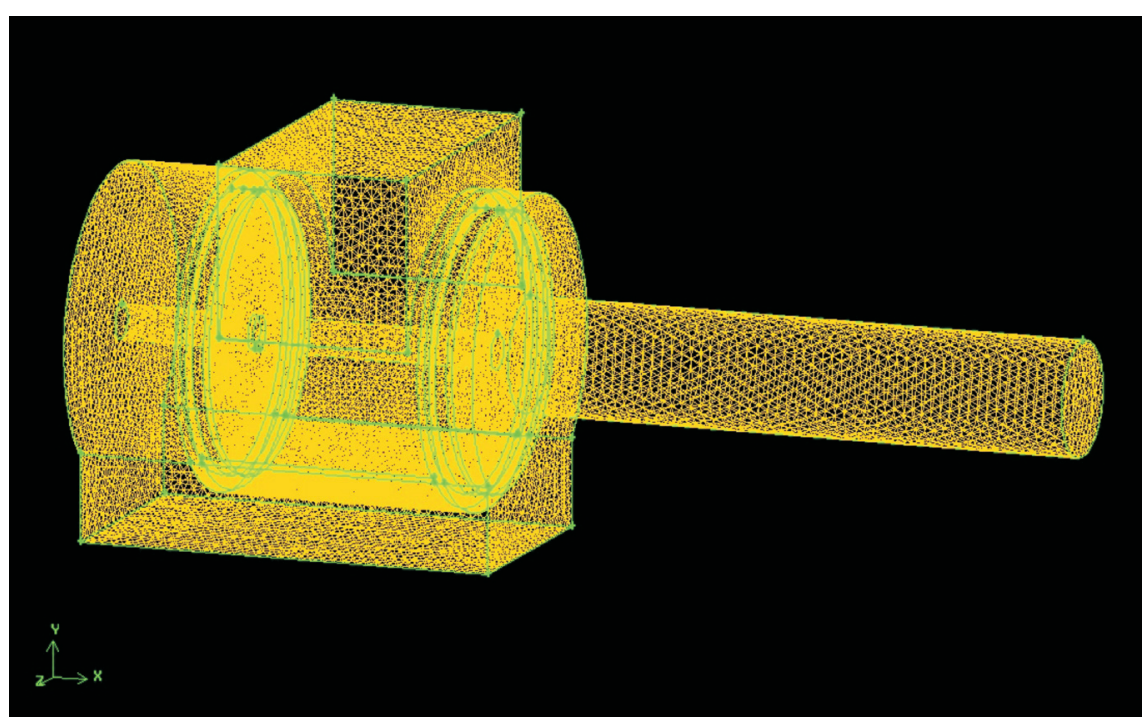

Fig. 3. Discretization of calculation area in Gambit Rys. 3. Dyskretyzacja obszaru obliczeniowego w programie Gambit wzorowanie rzeczywistej geometrii elementu [4]. Do tego celu wykorzystano program GAMBIT (rys. 2) a następnie, dokonano dyskretyzacji obszaru obliczeniowego (rys. 3) przy zastosowaniu siatki tetraedrycznej (Tetrahedral/Hybrid) dla zaworu EGR. Wygenerowana siatka została dodatkowo, celowo zagęszczona w obszarze grzybków zaworowych. Ponieważ, w tym miejscu spodziewano się największych zmian prędkości i ciśnienia gazu, a także wywołanych zwężeniem na celu zwiększenie dokładności obliczeniowej, a co za tym idzie większej precyzji odwzorowania zjawisk zachodzących w tych obszarach zaworu.

Dane wejściowe do symulacji określono na podstawie przeprowadzonych wyników badań eksperymentalnych. Zasymulowano przepływ strumienia powietrza przez zawór EGR dla różnych wysunięć grzybków zaworowych, przy stałej różnicy ciśnień $\Delta \mathrm{P}=10 \mathrm{kPa}$.

$\mathrm{Z}$ badań eksperymentalnych [3] wynika, że skuteczny zakres sterowania przepływem przez badany zawór EGR istnieje dla zakresu wysunięć od $\mathrm{h}=0,1$ do $\mathrm{h}=1,2 \mathrm{~mm}$ pomimo, że możliwe jest wysunięcie grzybka zaworu do $\mathrm{h}=5 \mathrm{~mm}$. Symulacje przepływu przeprowadzono dla trójwymiarowego modelu zaworu EGR, dla wysunięć grzybków zaworowych $\mathrm{h}=0,1 \mathrm{~mm}$, $\mathrm{h}=0,6 \mathrm{~mm}$ oraz $\mathrm{h}=1 \mathrm{~mm}$.

\section{Zmiany prędkości gazu przepływającego przez zawór EGR}

W trakcie badań symulacyjnych dokonano porównania różnych parametrów turbulencji przepływu. Większa ilość węzłów siatki miała 
for position range of $h=0.1$ and $h=1.2 \mathrm{~mm}$, although it is possible to eject the valve head to the $h=5 \mathrm{~mm}$. Flow simulations for three-dimensional model of the EGR valve for the valve heads positions $\mathrm{h}=0.1 \mathrm{~mm}, \mathrm{~h}=0.6 \mathrm{~mm}$ and $\mathrm{h}=1 \mathrm{~mm}$ were performed.

\section{Changes in the velocity of the gas flowing through the EGR valve}

In simulation research various parameters of the gas flow through EGR valve, including velocity and pressure, was examined. In Fig. 4 the gas velocity vectors for the subsequent openings of the valve were presented.

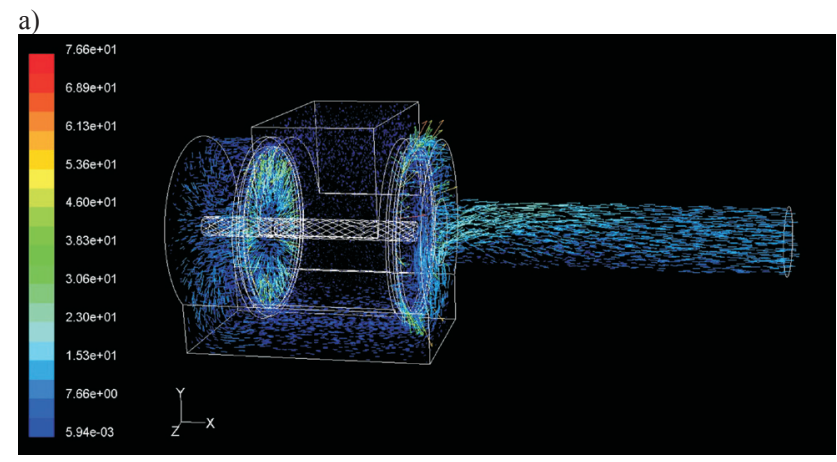

b)
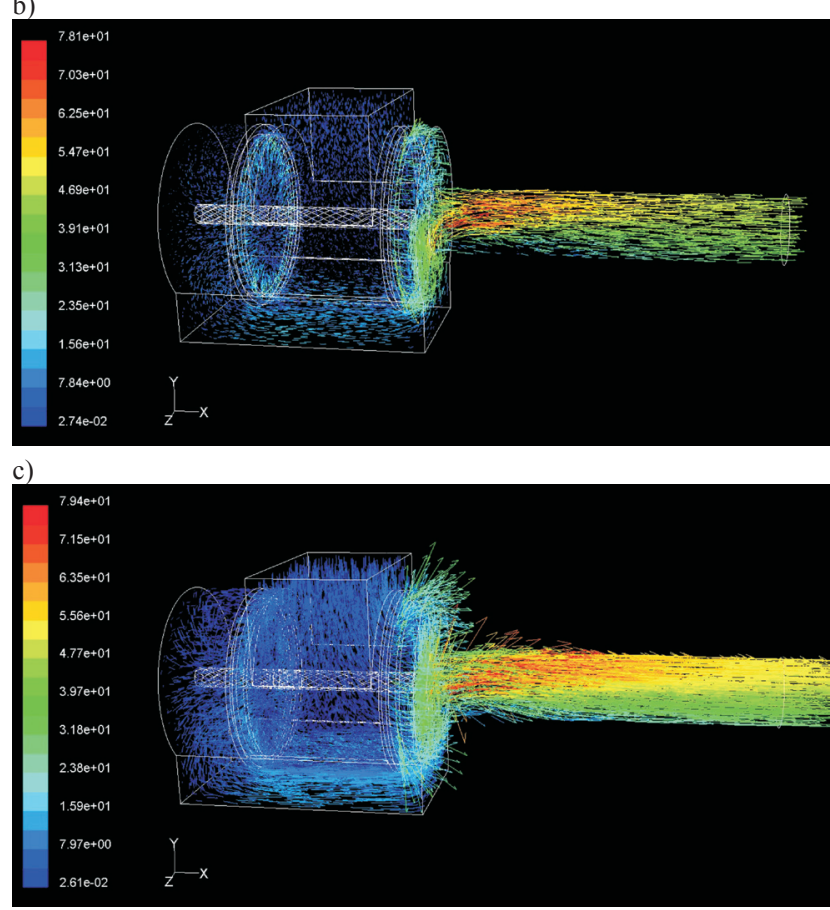

Fig. 4. Vectors of the gas flow velocity in the EGR valve for the following positions of valve head a) $\mathrm{h}=0.1 \mathrm{~mm}, \mathrm{~b}) \mathrm{h}=0.6 \mathrm{~mm}, \mathrm{c}) \mathrm{h}=1 \mathrm{~mm}$ Rys. 4. Wektory prędkości przeplywu gazu przez zawór EGR dla kolejnych wysunięć grzybków zaworowych a) $h=0,1 \mathrm{~mm}, b) h=0,6 \mathrm{~mm}, c) h=1 \mathrm{~mm}$

For better illustration of velocity vectors, the valve was cut by a vertical plane and the results were shown in Fig. 5 .

With the opening of the valve increase of velocity of gas flow was observed, which was shown on the following figures. Characteristic disproportion in gas flow velocity in the valve seat area can be seen. With the opening of the valve przepływu gazu przez zawór EGR m.in. prędkości i ciśnienia. Na rysunku 4 zostały przedstawione wektory prędkości gazu dla kolejnych wartości wysunięcia grzybków zaworowych.

Dla lepszego zobrazowania wektorów prędkości przedstawiono je na rysunku $5 \mathrm{w}$ przekroju zaworu płaszczyzną pionową.

Wraz ze zwiększeniem stopnia otwarcia grzybka zaworu zaobserwowano zwiększanie się prędkości przepływu, co przedstawiają kolejne rysunki. Zauważalna jest charakterystyczna dysproporcja w prędkości przepływu gazu w obszarze gniazd zaworowych. Wraz z wysuwaniem się grzybków zaworowych zwiększa się prędkość gazu po stronie wylotu zaworu EGR. Ponieważ średnica grzybka zaworowego różni się wyraźnie od średnicy otworu wylotowego z zaworu, zaobserwowano oddziaływanie tzw. kryzy, które objawia się wzrostem prędkości gazu w miejscu zmniejszenia się średnicy, a także ograniczeniem przepływu. Zjawisko ograniczonego przepływu zostało zaobserwowane w badaniach ekspe-
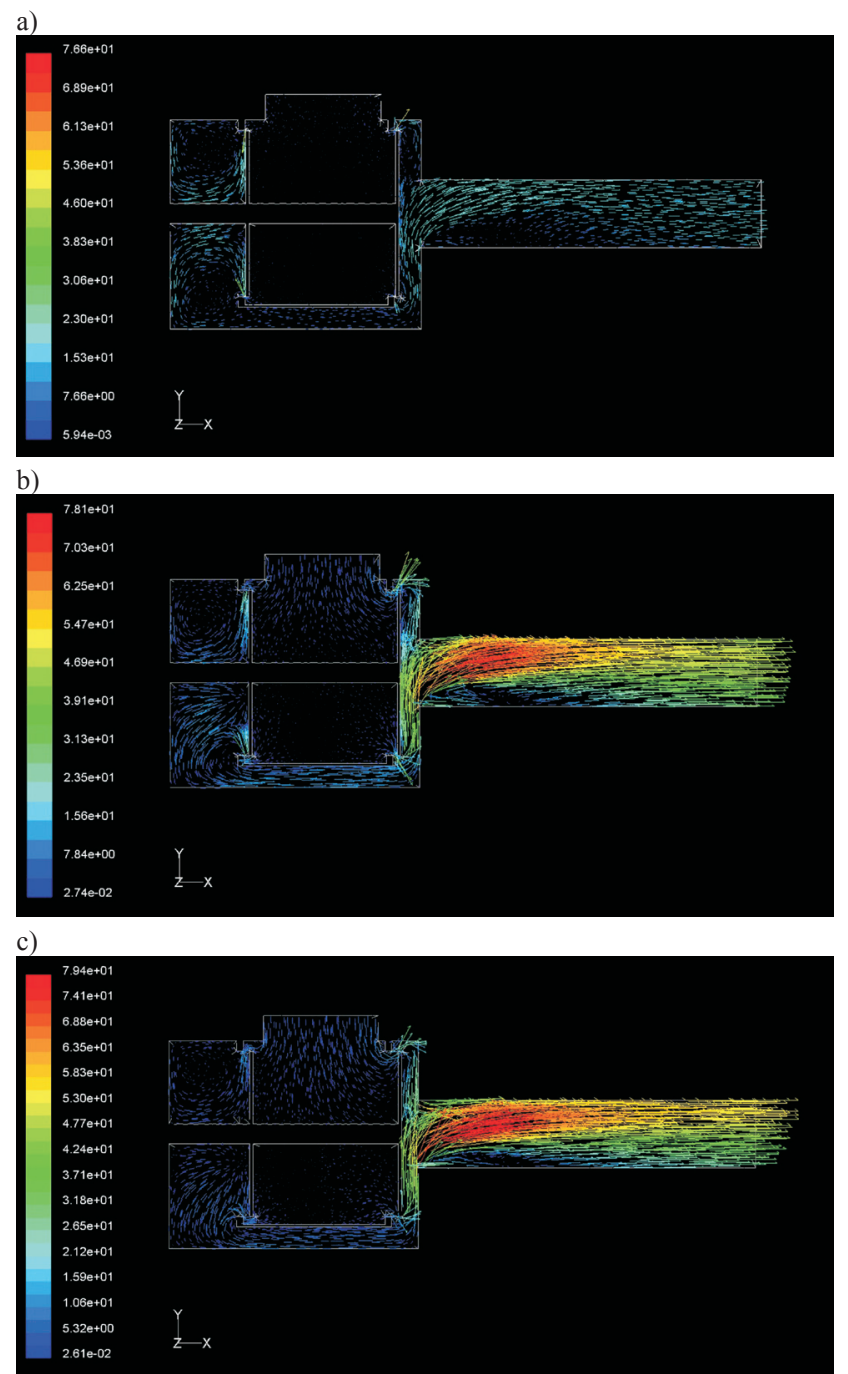

Fig. 5. Vectors of the gas flow velocity in the EGR valve, in longitudinal cross section, for the following positions of valve heads a) $h=0.1 \mathrm{~mm}$, b) $\mathrm{h}=0.6 \mathrm{~mm}, \mathrm{c}) \mathrm{h}=1 \mathrm{~mm}$

Rys. 5. Wektory prędkości przeplywu gazu przez zawór EGR, w przekroju płaszczyzną pionowa, dla kolejnych wysunięć grzybków zaworowych a) $h=0,1 \mathrm{~mm}, b) h=0,6 \mathrm{~mm}, c) h=1 \mathrm{~mm}$ 
the velocity of the gas on the outlet side of the EGR valve increases. Because diameter of the valve head is significantly different from the diameter of the valve outlet, the orifice effect was observed. It reveals by an increase of gas velocity and also flow limitation at the area of narrowing of the flow cross section. Limited flow phenomenon has been observed in experimental studies, which showed that the valve opening in the range from $\mathrm{h}=1.2$ and $\mathrm{h}=5 \mathrm{~mm}$ had no effect.

\section{Changes of pressure in the exhaust gas recirculation valve}

In the next stage of research changes in pressure in the EGR valve was analyzed. On Fig. 6 distribution of gas pressure for the subsequent stapes of valve opening is presented. It was observed, that for small value of opening of the valve $\mathrm{h}=0.1 \mathrm{~mm}$ (Fig. 6a), the use of a solution with two heads is justified by the fact that the pressure difference is small, so the forces acting on the heads are balanced, which means that the force required to move them is relatively small. With
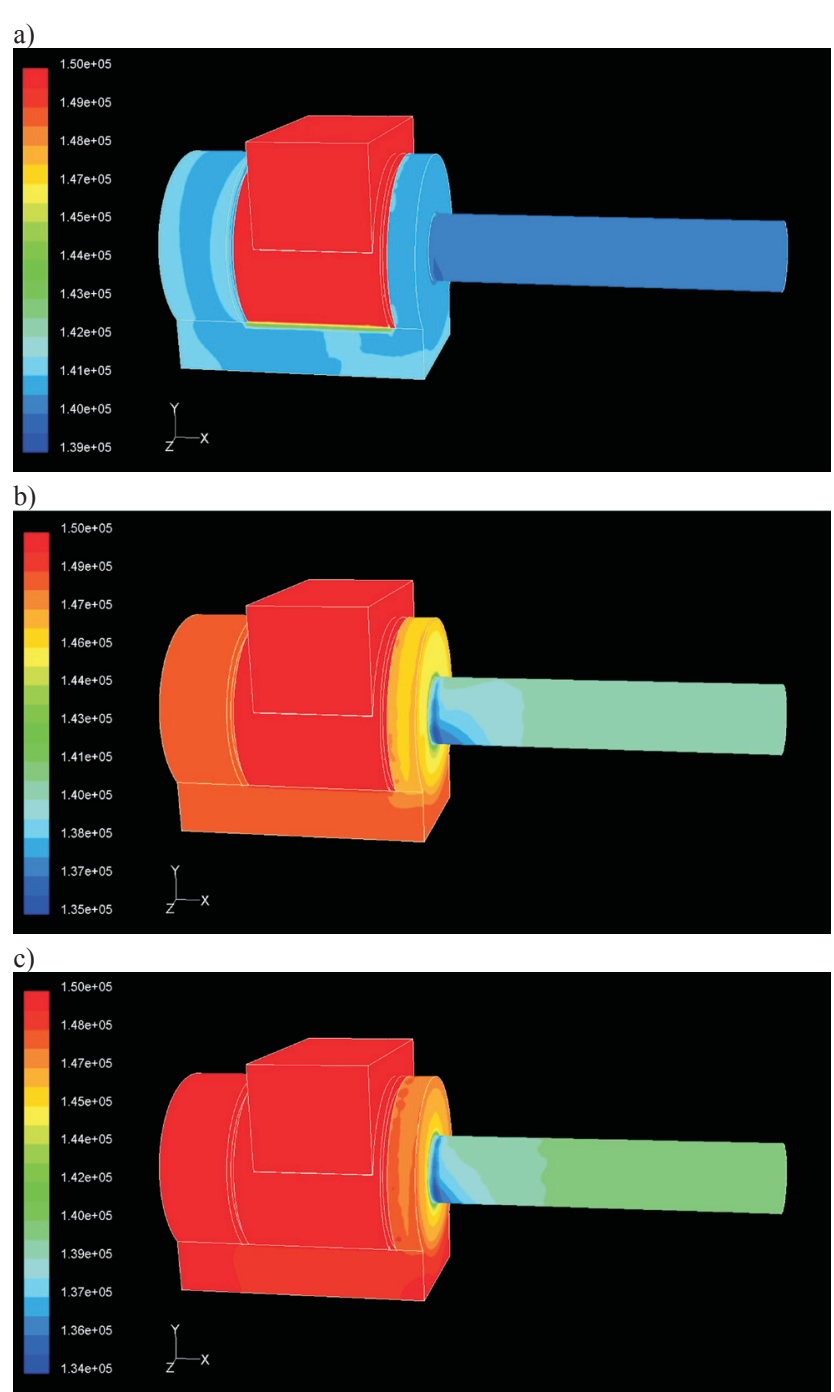

Fig. 6. Pressure of gas for the following positions of valve heads a) $\mathrm{h}=0.1 \mathrm{~mm}$, b) $\mathrm{h}=0.6 \mathrm{~mm}, \mathrm{c}) \mathrm{h}=1 \mathrm{~mm}$

Rys. 6. Ciśnienie gazu przy kolejnych wysunięciach grzybków zaworowych a) $h=0,1 \mathrm{~mm}, b) h=0,6 \mathrm{~mm}$, c) $h=1 \mathrm{~mm}$ rymentalnych, w których wysunięcie grzybka zaworu w zakresie od $\mathrm{h}=1,2$ do $\mathrm{h}=5 \mathrm{~mm}$ nie przynosi efektu.

\section{Zmiany ciśnienia w zaworze recyrkulacji spalin}

Dla analizowanego zakresu otwarcia grzybka zaworowego w kolejnym etapie badań symulacyjnych przeanalizowano zmiany ciśnienia w zaworze EGR. Na rysunku 6 przedstawiony został rozkład ciśnienia w zaworze dla kolejnych wysunięć grzybków. Zaobserwowano, że dla małych wysunięć zaworu $\mathrm{h}=0,1 \mathrm{~mm}$ (rys. 6a), zastosowanie rozwiązania konstrukcyjnego z dwoma grzybkami jest uzasadnione tym, że różnica ciśnień jest niewielka, a tym samym siły działające na grzybki równoważą się, co oznacza że siła potrzebna do ich przesunięcia jest stosunkowo niewielka. Wraz ze zwiększaniem się wysunięcia zaworu zwiększa się różnica ciśnień. W tym przypadku również, analizowana tzw. kryza, przedstawiająca miejsce zwężenia przekroju, spowodowana

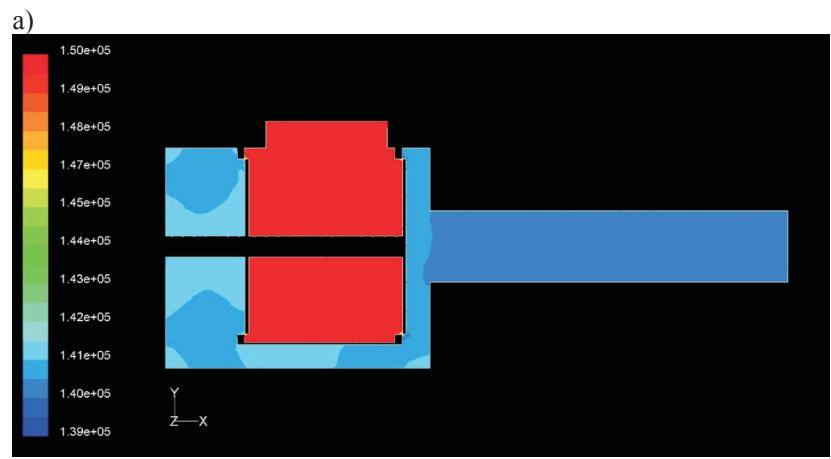

b)

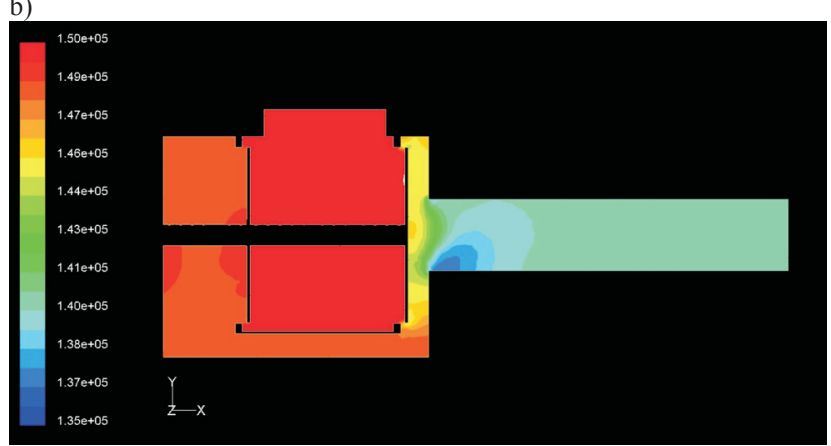

c)

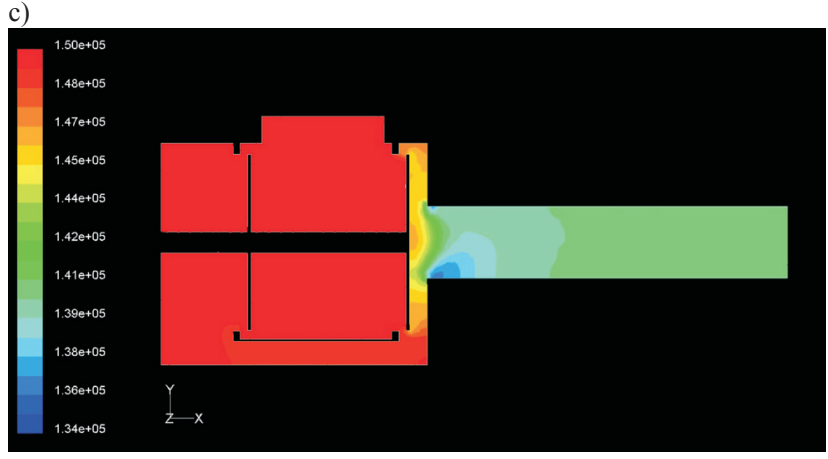

Fig. 7. Pressue of gas in the EGR valve, in longitudinal cross section, for the following positions of valve heads a) $h=0.1 \mathrm{~mm}, b) h=0.6 \mathrm{~mm}$,

$$
\text { c) } \mathrm{h}=1 \mathrm{~mm}
$$

Rys. 7. Ciśnienie gazu przez zawór EGR, w przekroju płaszczyzna pionowa, dla kolejnych wysunięć grzybków zaworowych a) $h=0,1 \mathrm{~mm}$, b) $h=0,6 \mathrm{~mm}, c) h=1 \mathrm{~mm}$ 
the increase in opening of the valve differential pressure increases. In this case also narrowing of flow cross section (orifice) causes the phenomenon of local pressure drop.

For the analysis of the distribution of pressure in the EGR valve, a similar methodology was used as that shown in the previous paragraph - the valve was cut by the vertical plane. Distribution of pressure for the analyzed valve is shown in Fig. 7. Figures illustrate changes of pressure distribution with increasing valve oppening.

Analyzing the distribution of pressure in the valve, it can be seen that gas pressure increases much faster on the siede of valve head 10 (Fig. 1) than on the side of the valve head 9. Whereas in the area of valve head 9 and the outlet tube can be seen gradual changes of pressure and differences in the distribution of pressure between the upper and lower part of the valve. It is significance that there is an existing bypass channel 7 (Fig. 1), such that the pressure in lower area of the valve head 9 increases faster than the upper. There is also a low pressure zone in the lower area of the outlet tube directly behind the outlet of the valve flange (element 6, Fig. 1).

\section{Turbulence of the gas flow}

In the simulation studies an analysis of changes in the turbulence of the gas flow through the exhaust gas recirculation valve was also made. Figure 8 shows the turbulence of the flow for subsequent openings of the valve. It can be seen that the greatest turbulences were in the area of valve head (element 9, Fig. 1) and the outlet of the valve. Turbulence increases with increasing opening of the valve and thus with increasing gas flow.

Figure 9 shows the turbulences of the gas flow in valve after the intersection by the vertical plane for the following openings of valve a) $\mathrm{h}=0.1 \mathrm{~mm}, \mathrm{~b}) \mathrm{h}=0.6 \mathrm{~mm}$, c) $\mathrm{h}=1 \mathrm{~mm}$

There is a significant increase of turbulence in the gas flow around the valve heads and area of the connection of the valve with outlet tube, and then also in the same tube.

These are the areas where there are turbulences caused by the differences in speed of flowing gas resulting from the shape of the valve.

\section{Verification of the calculation model}

In the paper the verification of calculation model was made. The results of simulation research for the mass flow with those obtained experimentally were compared, for differential pressure $\Delta \mathrm{P}=10 \mathrm{kPa}$ and $\Delta \mathrm{P}=30 \mathrm{kPa}$ (Fig. 10).

Comparison of the mass flow obtained by numerical simulations with experimental values showed convergence, and the relative error does not exceed $15 \%$. On the above figures to each measurement point range \pm 15 $\%$ of its value was assigned. Because mass flow is represented with $15 \%$ accuracy we can assumed that the phenomena of flow obtained in the simulations are similar to the real one. zmianą średnicy otworu wylotowego, powoduje zjawisko lokalnego spadku ciśnienia.

Do analizy rozkładu ciśnienia w zaworze EGR, zastosowano podobną metodykę jak w przypadku pokazywanym w poprzednim punkcie wektorów prędkości, gdzie dokonano przecięcia zaworu w płaszczyźnie pionowej. Rozkład ciśnienia dla analizowanego zaworu przedstawiono na rys. 7. Kolejne rysunki obrazują zmiany ciśnienia gazu wraz ze zwiększaniem wysunięcia grzybków zaworu

Analizując rozkład ciśnienia w zaworze zauważyć można, że po stronie grzybka zaworowego 10 (rys. 1) ciśnienie gazu wzrasta znacznie szybciej niż po stronie grzybka zaworowego 9. Natomiast w obszarze grzybka zaworowego 9 oraz rurki wylotowej można zauważyć następujące stopniowo zmiany ciśnienia i pojawiające się różnice w rozkładzie ciśnień pomiędzy górną i dolną częścią zaworu. Nie bez znaczenia jest tu istniejący kanał bypass 7 (rys. 1), dzięki któremu ciśnienie w dolnym obszarze grzybka zaworowego 9 zwiększa swoją wartość szybciej niż w obszarze górnym. Widoczna jest także strefa niskiego ciśnienia w dolnej strefie rurki wylotowej, bezpośrednio za otworem wylotowym w kołnierzu zaworu (element 6, rys. 1).

\section{Turbulencje przepływu}

W badaniach symulacyjnych dokonano również analizy zmian turbulencji przepływu gazu przez zawór recyrkulacji spalin. Na rysunku 8 przedstawiono turbulencje przepływu dla kolejnych wysunięć grzybków zaworowych. Można zaobserwować, że największe turbulencje występują w obszarze grzybka zaworowego (element 9, rys. 1) oraz wylotu z zaworu. Turbulencje zwiększają się wraz ze wzrostem wysunięcia zaworu, a tym samym wraz ze zwiększonym przepływem gazu.

Rysunek 9 przedstawia turbulencje przepływu gazu po dokonaniu przecięcia zaworu w płaszczyźnie pionowej, dla kolejnych wysunięć grzybków zaworowych a) h =0,1 mm, b) $\mathrm{h}=0,6 \mathrm{~mm}, \mathrm{c}) \mathrm{h}=1 \mathrm{~mm}$, analogicznie jak poprzednio.

Zauważalny jest wyraźny wzrost turbulencji w obszarze przepływu gazu przez grzybki zaworowe oraz w miejscu połączenia zaworu z rurką wylotową, a następnie także w samej rurce. Są to obszary, w których występują zawirowania gazu spowodowane różnicami prędkości przepływającego gazu wynikającymi z ukształtowania zaworu.

\section{Weryfikacja modelu obliczeniowego}

W pracy dokonano weryfikacji przyjętego modelu obliczeniowego. W tym celu porównano otrzymane wyniki badań symulacyjnych dla przepływu masowego z danymi uzyskanymi eksperymentalnie, dla różnic ciśnień $\Delta \mathrm{P}=$ $=10 \mathrm{kPa}$ oraz $\Delta \mathrm{P}=30 \mathrm{kPa}$ (rys. 10).

Dokonując porównania wartości przepływu masowego dla przepływów uzyskanych w wyniku symulacji numerycznych z wartościami eksperymentalnymi wykazało zgodność, a błąd względny nie przekraczał $15 \%$. Na powyższych wykresach każdemu punktowi pomiarowemu przypisano przedział $\pm 15 \%$ jego wartości. Ponieważ przepływ masowy jest odwzorowany z 15 \% dokładnością można założyć, że zjawiska przepływowe uzyskane w symulacjach dają obraz zbliżony do rzeczywistego. 

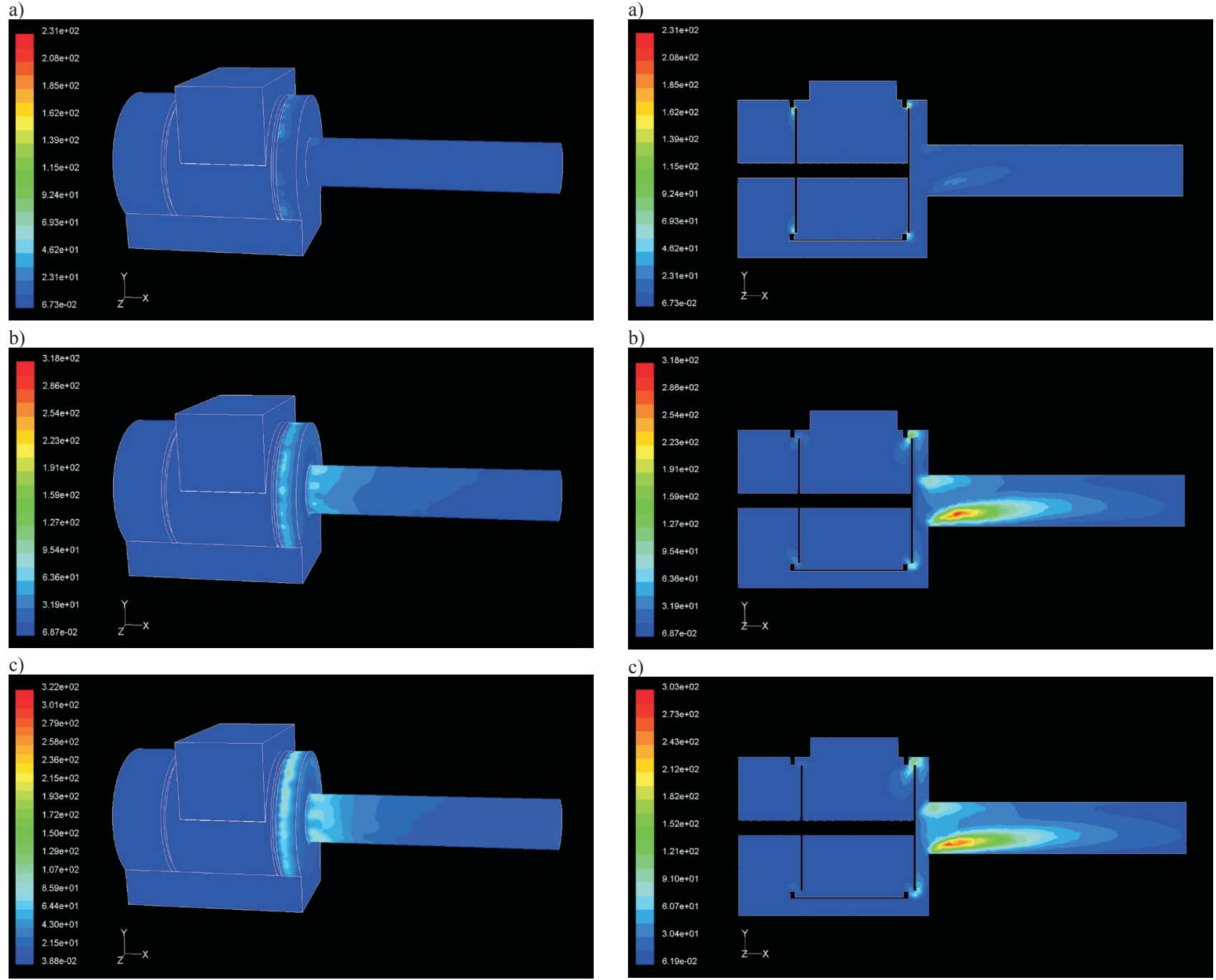

Fig. 8. The turbulence of the gas flow for subsequent openings of valve) $\mathrm{h}=0.1 \mathrm{~mm}, \mathrm{~b}) \mathrm{h}=0.6 \mathrm{~mm}, \mathrm{c}) \mathrm{h}=1 \mathrm{~mm}$

Rys. 8. Turbulencje przeptywu gazu przy kolejnych wysunięciach grzybków zaworowych a) $h=0,1 \mathrm{~mm}, b) h=0,6 \mathrm{~mm}$, c) $h=1 \mathrm{~mm}$

Fig. 9. The turbulence of the gas flow through the EGR valve, in longitudinal cross for the following openings of the valve) $h=0.1 \mathrm{~mm}$,

b) $\mathrm{h}=0.6 \mathrm{~mm}, \mathrm{c}) \mathrm{h}=1 \mathrm{~mm}$

Rys. 9. Turbulencja przeplywu gazu przez zawór EGR, w przekroju plaszczyzna pionowa, dla kolejnych wysunięć grzybków zaworowych a) $h=0,1 \mathrm{~mm}, b) h=0,6 \mathrm{~mm}, c) h=1 \mathrm{~mm}$

a)

b)
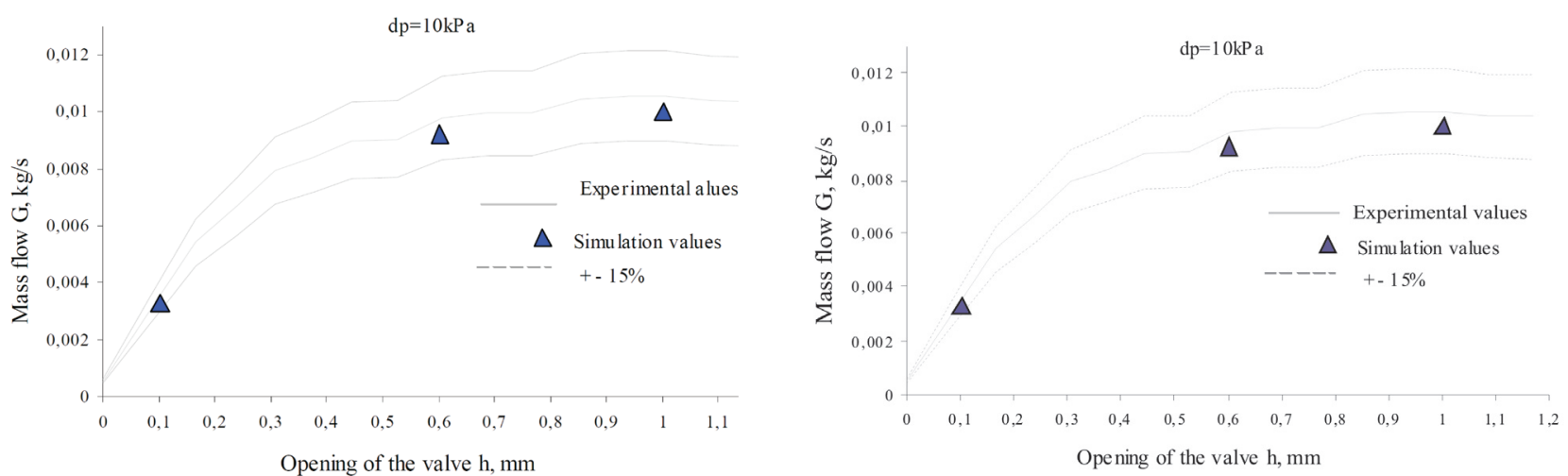

Fig. 10. Comparison of the mass flow resulting from the calculations with the experimental data. For differential pressure a) $\Delta \mathrm{P}=10 \mathrm{kPa}$ and b) $\triangle \mathrm{P}=30 \mathrm{kPa}$

Rys. 10. Porównanie wartości przepływu masowego powietrza przez zawór EGR uzyskanych w wyniku obliczeń numerycznych z danymi eksperymentalnymi. Dla różnic ciśnień a) $\triangle P=10 \mathrm{kPa}, \mathrm{b}) \Delta P=30 \mathrm{kPa}$ 


\section{Summary}

As the summary can be concluded that chosen simulation research model, discretization of calculation area made for subsequent openings of valve (very important for the proper simulation of the process) and the use of tetrahedral mesh proved to be the right solution. Comparison of the mass flows obtained by numerical simulations with experimental values showed convergence.

Analysis of velocity vectors, pressure distribution and flow turbulence for subsequent openings of valve allowed to claim, that for the small openings of the valve construction with two valve heads is appropriate because of the balancing of forces. Thus, the forces required to move the valve stem are small. Narrowing of the diameter of the outlet of the valve so called orifice was observed. This element causes reduction of the gas flow, increase of flow velocity, local pressure drop and also occurrence of turbulence of gas in this area. So it can be assumed that increasing of the diameter of the valve outlet could extend the contol range of the EGR valve and also elimination of bypass channel.

\section{Podsumowanie}

Dokonując podsumowania można stwierdzić, że dobrany ramach badań symulacyjnych model do obliczeń numerycznych, dokonana dyskretyzacja obszaru obliczeniowego dla kolejnych wysunięć zaworu (niezwykle istotna ze względu na prawidłowe symulowanie procesu) oraz zastosowanie siatki tetraedrycznej okazały się trafnym rozwiązaniem, gdyż porównanie wartości przepływów masowych uzyskanych w wyniku symulacji numerycznych z wartościami eksperymentalnymi wykazało zgodność.

Porównanie rozkładu wektorów prędkości, rozkładu ciśnienia jaki i turbulencji przepływu dla kolejnych wysunięć grzybków zaworowych pozwoliło zauważyć, że przy niewielkich wysunięciach konstrukcja zaworu EGR z dwoma grzybkami zaworowymi jest uzasadniona, z powodu równoważenia się sił. Tym samym siły potrzebne do przesunięcia trzonu zaworu, w zakresie małych wysunięć, są niewielkie. Zwrócono uwagę na występujące na wylocie zaworu zwężenie średnicy tzw. kryzy. Element ten powoduje jednocześnie ograniczenie przepływu gazu, zwiększenie prędkości przepływu i lokalny spadek ciśnienia, jak również występowanie turbulencji gazu w tym obszarze.

Zatem można domniemywać, że zwiększenie średnicy wylotowej z zaworu, mogłoby pozwolić na rozszerzenie zakresu sterowania zaworem EGR, a tym samym likwidacji występującego w badanym silniku kanału obejściowego.

\section{Nomenclature/Skróty i oznaczenia}

EGR Exhaust Gas Recirculation/uktad recyrkulacji spalin

\section{Bibliography/Literatura}

[1] Fluid Dynamics Analysis Package. Fluid Dynamics International, Inc. 2007.

[2] Ferziger J.H., Perić M., Computational Methods for Fluid Dynamics. Springer-Verlag, Berlin Heidelberg 1999.
[3] Bieniek A. (red.): Zasilanie silników wysokoprężnych pojazdów pozadrogowych, Monografia Z. 312, Oficyna Wydawnicza Politechniki Opolskiej 2012.

[4] Dobrowolski B., Jantos J., Lenc-Brol A., Mamala J.: Research of computer simulated phenomena in an air intake manifold of the spark ignition engine in time of short time supercharging, Combustion Engines, PTNSS-2009-SC-011, Opole 2009.
Jarosław Mamala, DSc., DEng. - Professor in the Faculty of Mechanical Engineering at Opole University of Technology.

Dr hab. inż. Jarosław Mamala - profesor na Wy dziale Mechanicznym Politechniki Opolskiej. e-mail:j.mamala@po.opole.pl

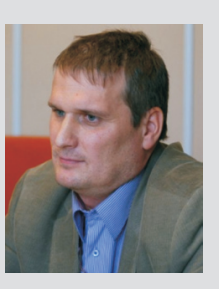

Agata Lenc-Brol, MEng. - PhD student in the Faculty of Mechanical Engineering at Opole University of Technology.

Mgr inż. Agata Lenc-Brol-doktorant na Wydziale Mechanicznym Politechniki Opolskiej. e-mail: a.lenc-brol@po.opole.pl 